
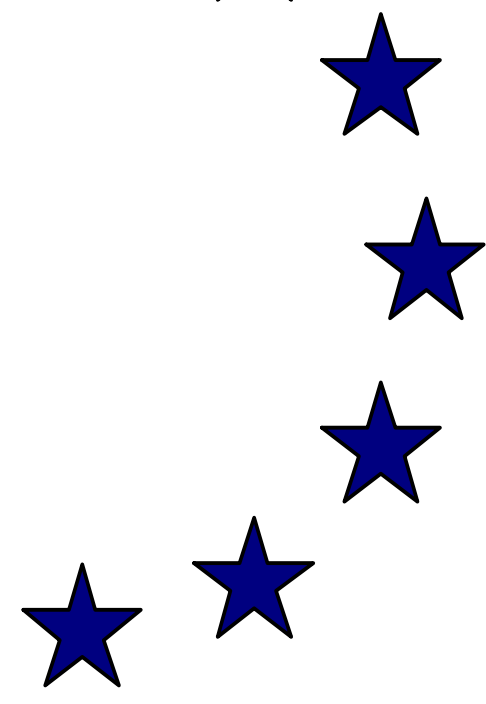

ISSN 1725-3187

http://europa.eu.int/comm/economy finance

$$
\mathrm{N}^{\circ} 218
$$

December 2004

Product market reforms and productivity: a review of the theoretical and empirical literature on the transmission channels by

Gaëtan Nicodème* and Jacques-Bernard Sauner-Leroy**

*Directorate-General for Economic and Financial Affairs

** Banque de France 
Economic Papers are written by the Staff of the Directorate-General for Economic and Financial Affairs, or by experts working in association with them. The "Papers" are intended to increase awareness of the technical work being done by the staff and to seek comments and suggestions for further analyses. Views expressed represent exclusively the positions of the author and do not necessarily correspond to those of the European Commission. Comments and enquiries should be addressed to the:

European Commission

Directorate-General for Economic and Financial Affairs

Publications

BU1 - $-1 / 180$

B - 1049 Brussels, Belgium

ECFIN/7140/04-EN

ISBN 92-894-8365-2

KC-AI-04-218-EN-C

C)European Communities, 2004 


\title{
Product market reforms and productivity: a review of the theoretical and empirical literature on the transmission channels
}

\author{
Gaëtan Nicodème* \\ European Commission, and Solvay Business School (ULB) \\ And \\ Jacques-Bernard Sauner-Leroy \\ Banque de France
}

December 2004.

\begin{abstract}
Product market reforms are structural reforms of microeconomic type that aim at improving the functioning of product markets by increasing competition amongst producers of goods and services. Theoretical models suggest that regulation and reforms which liberalise or improve the functioning of markets can positively affect productivity through three different channels, namely a reallocation of scarce resources (allocative efficiency), an improvement in the utilisation of the production factors by firms (productive efficiency) and an incentive for firms to innovate to move to the modern technology frontier (dynamic efficiency). This paper reviews the theoretical and empirical literature on these three channels.
\end{abstract}

Keywords: product markets reforms, competition, productivity, efficiency

JEL codes: O12, O30, O40.

The findings, interpretations, and conclusions expressed in this paper are entirely those of the authors. They should not be attributed to the European Commission nor to the Banque de France. Helpful comments from Fabienne Ilzkovitz, Una Oligbo and Jan Schmidt are gratefully acknowledged. Errors and omissions are entirely those of the authors. Corresponding author: gaetan.nicodeme@,cec.eu.int 


\section{INTRODUCTION}

Economic literature has largely demonstrated the importance of productivity for economic growth and welfare, decomposing GDP per capita into five components (Denis, McMorrow and Röger, 2004):

$$
\frac{G D P}{P O P}=\frac{G D P}{H} \times \frac{H}{L} \times \frac{L}{L F} \times \frac{L F}{W A P} \times \frac{W A P}{P O P}
$$

Where $\mathrm{H}$ denotes the average number of hours worked, L represents employment; LF is the labour force and WAP the working-age population (European Commission, 2000). Among these factors, the one that influences economic growth the most over the long term is labour productivity since the other factors - labour inputs - cannot be increased infinitely (European Commission, 2000).

One way of stimulating productivity growth performances is to enhance competition through policies that aim to improve the functioning of product markets by deregulating and facilitating entry or the threat of entry (Nicoletti and Scarpetta, 2003). These kind of measures, which are defined as product market reforms (PMR), are at the heart of the EU strategy decided in 2000 in Lisbon to become the most competitive and dynamic knowledgebased economy with sustainable economic growth and greater social cohesion by 2010. A major aim of these reforms is indeed to increase GDP per capita that currently stands for the EU-25 at only around $65 \%$ of the US level.

Product market reforms impact on economic performance through the stimulation of productivity via three main channels of transmission, namely a reallocation of resources (allocative efficiency), an improvement in the utilisation of production factors by firms (productive efficiency) and an incentive for firms to innovate (dynamic efficiency). However, the sequence of their respective impact on productivity growth has rather been overlooked. The aim of this paper is to propose such a sequence and to present a review of both the theoretical and empirical literatures on these three transmission channels. In the theoretical models we refer to, the links between product market reforms and productivity are indirect and act through those three channels. We do not cover as such the direct links that may exist between product market reforms and productivity. These direct links include for example 
lower costs of doing business thanks to reduced administrative burden or lower barriers to trade.

Section one presents the main conclusions drawn from both the theoretical and empirical literature on the links between PMR, allocative efficiency and productivity. Sections two and three provide the same elements as regards the two other channels of the productive and dynamic efficiency, respectively. Finally, the last section attempts to present a synthetic view of the sequence the three channels impact on productivity and to draw some policy implications.

\section{PRODUCT MARKET REFORMS, ALLOCATIVE EFFICIENCY AND PRODUCTIVITY.}

Competition leads to reallocation of resources between and inside firms.

By increasing the number of competitors or the threat of entry of new competitors in each market, product market reforms lead to markets that are more competitive. The increase in the contestability of markets and the reduction of the incumbent's market power incite firms to set prices closer to marginal costs. As a consequence, mark-ups tend to decrease while the allocation of both inputs (labour and capital) and goods is more efficient, i.e. scarce resources are allocated to the production of the goods and services so that consumer wants and needs are met in a better way than they were in the previous period. More product market competition can also lead to increased allocative efficiency as less productive firms exit and market share moves from less productive to more productive firms.

\section{Reallocation of resources positively influences performance.}

These theoretical models that focus on the reallocation effects of liberalisation generally consider that the latter has a positive impact on economic performance. For instance, Melitz (2003) specifies a model with imperfect competition and heterogeneous firms in which opening to trade leads to a reallocation of resources towards more productive firms within industries. Low productivity firms exit, high productivity firms expand in the domestic market and some enter the export market. This leads to an increase in aggregate productivity, even when there is no productivity growth within the firms. However, a rise in competition does not always lead to increased allocative efficiency. For example, Vickers (1995) points out that an increase in competition through more aggressive interactions between firms could increase industry concentration in the medium term since more aggressive firm' behaviour first 
reallocates profits from inefficient firms to more efficient ones (reallocation effect) and subsequently drives out inefficient firms (selection effect). This thereby raises industry concentration and mark ups, but this model implies that market entry is not possible for new competitors, and so does not present the whole picture.

\section{Empirical studies largely confirm the theoretical analysis.}

Most empirical studies that aimed to test the links between the degree of market opening and/or the degree of competition, on the one hand, and the profitability level of firms, on the other hand, have found - since the pioneering works of Bain (1951 and 1956) - a negative relationship between these two variables, therefore confirming the theoretical analysis (Schmalensee, 1989). Jacquemin and Sapir (1991), for instance, showed that national industrial sectors in Europe that were protected from intra-EU competition by important nontariff barriers benefited in the early 80's from abnormally high profitability levels. More recently, Oliveira Martins et al. (1996) did not find any correlation between the degree of market concentration and the level of mark-ups but identified a significant negative correlation between entry rates in a market and mark-ups. The European Commission (1996) also showed that the implementation of the Single Market Programme led to an increase in competitive pressures in the manufacturing industry, resulting, in particular, in reductions in the price-cost margins. Allen et al. (1998) shared this conclusion. Griffith and Harrison (2004) estimated the relationship between product market reforms and the level of economic rents. They found that reforms that ease entry, reduce tariff rates and regulatory barriers to trade, remove price controls and reduce public involvement in production negatively affect the average level of economic rents in the economy.

\section{Internal restructuring appears to be the driving force behind allocative efficiency.}

Generally, studies analysing the impact of product market reforms on economic performance through the process of entry and exit focus for a large part on the link between entry and productivity, and generally find a positive link between the two indicators. One can decompose the direct impact of free entry and exit in several effects. First, internal restructuring (also called "within effect") refers to productivity growth of individual firms in the industry via factors internal to the firm such as organisational change, new technologies, or reallocation of inputs. Second, external restructuring represents a reallocation of resources among firms via a process of creative destruction with exit of least efficient firms or via a shift in market shares towards most efficient firms. Using OECD data, Barnes, Haskell and 
Maliranta (2001) found substantial within effects. Baily, Hulten and Campbell (1992) found similar results for the US manufacturing firms between 1972 and 1988 with significant impact of market share reallocation and only a small contribution of entry and exit. The same conclusion came out of research done by Griliches and Regev (1995) who surveyed the Israeli industry over 1979-1988. These three studies highlight the importance of within effects in impacting productivity growth.

\section{Contestability is key for reallocation to occur in the long-term.}

Blanchard and Giavazzi (2001) showed the importance of market entry - or more precisely the importance of market contestability - as a stimulus for competitive pressures and economic performance. In a model in which firms' and employees' productivity are fixed and in which labour is the only factor of production, they consider the impact of product market regulations. In their model, deregulation of product markets can take the form of either increased substitutability between goods or a reduction in entry costs. In the short run, increased substitutability between goods leads to lower mark ups, reduced unemployment and higher real wages. In the long term, the same results occur only if one reduces barriers to entry. If this fails to be the case, then firms exit because of lower level of rents and, as a result, mark ups, unemployment and real wages return towards their original levels. In this framework, liberalisation through the ease of firm/market entry is thus a major determinant of the effectiveness of product market reforms aimed at stimulating competition.

In a landmark study, Nicoletti and Scarpetta (2003) also demonstrated significant links between product market policies and productivity performance, with entry liberalisation leading to productivity gains in all of the countries considered regardless their position in terms of technology adoption. They also found evidence of a twofold effect of entry liberalisation that release their effects over a ten years time horizon. First, entry liberalisation in the services industries boosts annual multi-factor productivity growth in the overall business sector. Second, an indirect (and positive) effect of the removal of trade and administrative barriers to entry was found. The intensity of the effect depends on the technology gap that some countries accumulated in heavily regulated manufacturing industries. 


\section{Product market reforms help to shape business dynamism.}

Entry and exit of firms may in addition also affect allocative efficiency. Several factors explain entry and exit of firms. Among those, product market regulations stand out as having substantial impact on entry rate of businesses. Using principal component analysis, Cincera (2004) found that product market reforms have a positive impact on both entry and exit of companies. Brandt (2004) found that overly complicated license and permit system discourages the creation of new enterprises. In his study, Brandt used relatively conservative estimation techniques and the strong significance of his results is therefore an indication of robust findings. This also suggests that other regulations that his technique fails to find having statistically significant effects may actually also hinder entrepreneurship.

For example, one has so far rather overlooked the impact of tax policy as a product market reform. Business surveys identify differences in corporate tax systems across Europe as being a key obstacle to cross-border activities in Europe ${ }^{1}$. Moreover, some studies suggest a high compliance cost related to the lack of co-ordination of tax and accounting systems in Europe ${ }^{2}$. Besides these direct compliance costs, tax systems are known for having a large impact on entrepreneurship and on innovation activities, either through the general tax framework or through targeted tax policies (Gentry and Hubbard, 2004). The effect of taxation on entry is tricky to apprehend because entrepreneurs have the possibility to be self-employed or to incorporate ${ }^{3}$, therefore involving decisions based on both the personal and corporate income tax systems. In addition, not only the level but also the convexity of some tax systems mainly the progressivity of personal income tax systems - and the relative difficulties to carry-over losses across tax periods - leading in some cases to "success taxes" 4 - imply that decisions related to entrepreneurship also depend on the predicted level and distribution of earnings. Other types of taxation also matter. This is certainly the case for capital gains taxation, which has an effect on the level of venture capital supplied to entrepreneurs 5 .

\footnotetext{
1 See for example European Business Monitor, $12^{\text {th }}$ edition, 2002, page 16. Among a list of suggestions, leaders from top EU companies quote "further harmonisation of taxes across the EU" as the Single Market Policy that would benefit their company the most. http://ebm.ups.com

2 See European Commission (2001) and European Commission (2004).

3 In some cases, incorporation can be made so that entrepreneurs still face personal income taxes. This is for example the case of Personenunternehmen, such as the KG companies, in Germany. The design of tax rules will also have an impact on productivity through its incentives. This is for example the case for the taxation of performance-related pay systems, such as stock options or bonuses.

4 This is because losses do not lead to negative taxes. Therefore, successful companies usually face a higher effective taxation than unsuccessful ones.

5 A sizeable collateral damage of a lower supply of venture capital is the decrease in managerial advice that usually accompanies capital invested in risky activities (Keuschnigg and Nielsen, 2000).
} 
Finally, targeted tax measures - be they in terms of tax credits, specific depreciation rules, reduced taxation or preferential exemptions - have a large impact on entrepreneurial activities. The large effect of tax policy on entrepreneurial behaviour seems to be confirmed by the few studies on the topic ${ }^{6}$ (e.g. Cullen and Gordon, 2002).

However, allocative efficiency has mainly indirect effects, boosting productive and dynamic efficiency.

The welfare gains achieved by increasing allocative efficiency are not by themselves likely to be very large (Harberger, 1954; Leibenstein, 1966; Scherer and Ross, 1990). In fact, allocative efficiency gains mainly impact indirectly on economic performance by inciting firms to improve their productive efficiency and, although this is still a debated issue in the literature, to enhance efforts to innovate and speed up diffusion of innovation.

\section{Product Market Reforms, Productive EFFICIENCY AND PROdUCTIVITY.}

Productive efficiency forces companies to maximise the use of their resources.

Productive efficiency is the capacity for any given firm to allocate its resources in such a way that makes it possible to reduce or eliminate the under-utilisation of its production factors, i.e. capital and labour (Pilat, 1996). Productive efficiency and productivity are not identical concepts but they are interrelated (Sharpe, 1995) and a decrease in productive inefficiency can be associated with an increase in productivity (Pilat, 1996). In short, productive or technical efficiency gains come from the introduction of new or better production methods within the firm, including organisational changes.

Competition is likely to increase productive efficiency by reducing managerial slack.

The process through which competition influences productive efficiency relates to agency costs. Indeed, the main impact of higher product market competition on productive efficiency that the literature emphasises is the incentive effect on managers and workers to reduce slack, trim fat and structure the workplace more efficiently (Griffith and Harrison, 2004). Principalagent models under information asymmetry generally assume that managers and workers can partially capture monopoly rents to a monopolistic firm in the form of managerial slack, i.e.

6 In addition, the effect of tax systems on foreign direct investment is well-established, adding foreign competitors to the level of entry (see for example Clark, 2002). In a meta-analysis study, de Mooij and Ederveen (2001) found that the mean value of the tax rate elasticity to FDI was 3.3. 
lack of efforts. By giving them more incentives for increasing their efforts and improving efficiency, competitive pressures may reduce slack so that one can reasonably expect that product market competition would discipline firms into efficient operation (Ahn, 2001). This is because more competition reduces the agency costs because it allows stakeholders to better compare the efforts of managers with those of competitors. Empirically, the works of Holmstrom (1982), Nalebuff and Stiglitz (1983), and Mookherjee (1984) suggest that explicit incentives schemes will generate sharper incentives the larger the number of players involved. Hart (1983) also provides a model of managerial incentives that demonstrates explicitly how competition between firms may sharpen incentives. Incentives to improve productive efficiency could arise through different channels (Winston, 1993; Meyer and Vickers, 1997; Nickel et al., 1997; Aghion and Howitt, 1998):

- First, competition creates greater opportunities for comparing performance under information asymmetry and hence makes it easier for the owners or the market to monitor managers;

- Second, in highly competitive markets where price elasticity of demand is high, costreducing productivity improvements are likely to generate large increase in market shares and profit;

- Third, the probability of bankruptcy is likely to be higher in a more competitive environment. Consequently, managers have an incentive to step up their efforts to avoid such a failure.

Competition may also influence the effort of workers, as they are likely to capture a part of product market rents in the form of slack or higher wages. Therefore, there is a direct link between the degree of competition and the level of worker's effort (Nickell, 1996). Empirically, Griffith (2001) showed that the increase in product market competition brought about by the implementation of the Single Market Programme led to an increase in overall levels of efficiency in Europe. However, these efficiency gains occurred more particularly in firms where management and ownership were separated (principal-agents type of firms). This then suggests that product market competition can play an important role in reducing agency costs $^{7}$. Using American data, Jagannathan and Srinivasan (2000) came to a similar conclusion.

\footnotetext{
${ }^{7}$ Agency costs may be defined as costs induced by decisions taken by managers with the view to increasing their personal gratification or to reaching their own personal objectives (use of "free cash-flow") instead of being
} 
Sauner-Leroy (2003) also showed that the rise in competition induced by the implementation of the Single Market Programme led EU manufacturing firms to increase their productive efficiency to compensate for lower prices and profit margins.

Empirical studies show that competition and contestability increase productive efficiency.

Empirical studies analysing the links between product market reforms and productive efficiency are relatively scarce. The fact that productive efficiency is difficult to measure as it depends on various factors, some of them not being observable such as, for instance, organisational changes within companies (Sauner-Leroy, 2003) may explain this relative scarcity. Empirical works already been done on this issue mostly include studies focusing on the relationship between competition and productive efficiency, and not specifically on the relationship between product market reforms and productive efficiency. Nevertheless, one can argue that as product market reforms tend to increase competition, the conclusions drawn from empirical work linking competition and productive efficiency are also valid for the analysis of the links between product market reforms and productive efficiency. Caves and Barton (1990), Caves et al. (1992) or Green and Mayes (1991) used frontier production function techniques to compute efficiency indices and to relate them to competition variables. They found that, above a certain threshold, increases in market concentration (i.e. decreases in competition) tend to be associated with reductions in technical efficiency. Recently, Cincera (2004) found a positive and significant relationship between current firm entry and labour productivity growth as well as between exit lagged by two years and labour productivity growth.

Studies analysing the direct links between product market reforms (or competition) and productivity are more frequent. In particular, a number of empirical studies have sought to test the effects of trade liberalisation or of an increase in competition on the productivity level of industrial firms. These studies generally conclude that there is a positive relation (Nickell et al., 1997), either with respect to the impact of a trade barrier removal (Harrison, 1994; Mac Donald, 1994), or with respect to the impact of an increase in competition (Caves and Barton, 1990; Haskel, 1991; Green and Mayes, 1991; Nickell et al., 1992; Nickell, 1996; Pilat, 1996).

\section{PRODUCT MARKET REFORMS, DYNAMIC EFFICIENCY AND PRODUCTIVITY.}

taken in order to maximise the net present value of the firm. Agency costs may also stem from the existence of managerial or organisational slack translating into a misuse of human resources. 
In the long-term, product market reforms also potentially affect dynamic efficiency.

Gains through allocative and productive efficiency generally represent one-off changes to the level of productivity and output and accrue relatively rapidly, i.e. in the short run. However, an increase in competition may also act as a stimulus for firms to develop product and process innovations and hence to speed up the move to the modern technology frontier. Improvements in such dynamic efficiency gains potentially have a much larger impact on productivity but are also likely to take much longer to accrue, i.e. successful innovations will eventually raise the level and growth rate of total factor productivity in the long run (Ahn, 2002; Griffith and Harrison, 2004). However, the link between competition and innovation is a debated issue in the theoretical literature.

Schumpeterian models find that competition decreases the incentive for innovation. On the opposite, new endogenous growth models find that competition foster innovation.

Theoretical models have different views on the incentives created by increased competition. On one hand, in line with the Schumpeterian view of market power and innovation, the early endogenous growth and industrial organisation literatures suggested that increased product market competition led to reduced innovative activity, as more competition reduced the monopoly rents that reward successful innovators. Such results were found in the works of Dasgupta and Stiglitz (1980), Romer (1990) or Aghion and Howitt (1992). However, they were based on the assumption that innovation was made by outsiders or by new entrants competing incumbents with conventional technology and that the payoff of innovation was equal to the post-innovation rent (while the pre-innovation rent was zero).

On the other hand, new endogenous growth models - such as the ones developed by Aghion, Harris and Vickers (1997), Aghion and Howitt (1998) or Aghion, Harris, Howitt and Vickers(2001) - extend the basic Schumpeterian models by allowing incumbents firms to innovate and by assuming that innovation incentives mainly depend on the difference between the post-innovation and the pre-innovation rents. These models hence predict that more product market competition may end up fostering innovation. Aghion and Howitt (1998) offer two theoretical cases where competition is indeed conducive to innovation: 
- Intensified product market competition could force managers to speed up the adoption of new technologies in order to avoid loss of control rights consecutive to bankruptcy. Indeed, if successful innovators introducing new technology gain market shares because of more efficient production process, they will be able to replace the firms producing with the old technology. The latter are thus forced to innovate in order to survive (Ahn, 2002).

- In 'neck-and-neck' industries, i.e. in industries in which oligopolistic firms face similar production costs, product market competition will affect largely innovation. This is because intense competition increases each firm's incentive to reduce its production costs through the acquisition of a technological lead over its rivals. Competition may also increase the incentive of each firm to innovate to escape competition if, for instance, innovation translates into more sophisticated and differentiated products.

\section{Difficulties to measure dynamic efficiency led to contradictory results.}

The empirical literature on the link between product market competition and innovation has so far been relatively sparse and inconclusive. The reasons lay in the poor availability of comprehensive time series of product market indicators, in a "still-in-progress" theoretical framework, and in the difficulties of measuring dynamic efficiency given that it takes time to deliver its full effects and that innovation is difficult to measure. As surveyed by Ahn (2002, p.15), studies on the relationship between market power and innovation lead to mixed results. For example, some studies show that companies' size has no significant effects on innovation whilst other studies point to either a positive relationship between concentration and innovation, or an inverted U-Shaped relationship, or simply no effects when controlling for industry differences. Apparently, measurement and modelling issues blur empirical results as good proxies for innovation are difficult to find and regression methods fail to take into account "bounds" effects between R\&D intensity and concentration"

\footnotetext{
8 The "bounds approach" has been developed by John Sutton (see Sutton, 2002). Sutton looks at the determinants of market concentration and finds lower bounds for concentration. For example, R\&D can allow firms to differentiate their products and therefore more R\&D can lead to less concentration. Furthermore, Sutton would assume that as R\&D grow, market size matter less. Besides his focus on a lower bound, he also stresses that the relationship between concentration and market size is weaker for endogenous sunk costs that grow with market size such as research and development than for exogenous sunk costs. His work attempted to connect the analysis of concentration with the identification of the intensity of price competition and the level of endogenous sunk costs as the key determinants.
} 
The dominant effect probably depends on the type of industries and the technological gap.

In Schumpeterian models, the link between competition and innovation is ambiguous, as this link is prone to be positive in 'neck-and-neck' industries whereas it is prone to be negative in less 'neck-and-neck' - or more 'product-differentiated'- industries. In the latter type of industries indeed, more competition may reduce innovation as the laggard's reward to catching up with the technological leader may fall (Schumpeterian effect). Moreover, by increasing innovation incentives relatively more in 'neck-and-neck' industries than in 'product-differentiated' industries, an increase in product market competition will tend to reduce the fraction of 'neck-and-neck' industries in the economy in equilibrium. This effect reinforces the Schumpeterian effect in inducing a negative correlation between product market competition and aggregate productivity growth or aggregate rate of innovations (Aghion et al., 2002).

By introducing entry into such a type of model, Aghion et al (2003a) show that the effect of an increase in competition through (the treat of) entry depends on the country, industry or firm's distance to the world technological frontier. In countries that are close to the world technological frontier, fostering entry or competition will increase incumbents' incentives to innovate in order to escape potential entrants or new competitors. However, in countries or industries lagging far behind the world technological frontier, higher entry or higher competition tends to discourage incumbents from innovating. This model thus suggests that the overall impact of trade liberalisation will depend on the current state of technology in the country or the industry. However, in the long run, trade liberalisation will increase the overall average growth rate because in equilibrium there will be more industries where the affect is positive.

As predicted by the theoretical literature, the type of industry may matter. Acs and Audretsch (1987) found that different types of industries would produce innovative advantage for different sizes of industries. Small companies have innovative advantages in highly innovative and skilled-intensive sectors whereas large companies enjoy this advantage in more concentrated and capital-intensive industries. Using firm-level UK data, Blundell, Griffith and Van Reenen (1999) found that firms with higher market share innovated more but that at the industry level, more competitive industries were more innovative. Therefore, aggregate competition leads to more innovation but within the competitive industries dominant firms innovate more often. One difficulty is the possible endogeneity of market 
structure as it may itself be the result of innovation. In addition, although affecting $R \& D$ investment, regulations do not seem to be its main driver - some forms of protection could even be beneficial for risky R\&D activities - and market size and education appear to be more pronounced determinants (European Commission, 2003) .

\section{Market contestability appears to be a condition for dynamic efficiency.}

The direct link between competition and dynamic efficiency measured by productivity growth seems to be clear. Nickell (1996) found a positive impact of competition on firm-level TFP growth and Disney et al. (2000) found that external competition is an important determinant of internal restructuring, which in turn has an impact on TFP growth. In terms of relative importance, the authors distinguish between 'internal' restructuring (i.e. new technology and organizational change) and 'external' restructuring (i.e. entry of efficient firms and exit of least efficient ones) and find that 'external restructuring' accounts for $90 \%$ of TFP growth. Griffith and Harrison (2004) also find a non-linear relationship between competition and the growth rate of labour productivity or total factor productivity. When looking at the evolution of competition and the indicators of macroeconomic performance within countries, the authors find a negative relationship (i.e. more competition decreases performance). However, this finding has to be balanced by possible measurement errors and lag effects. Indeed, when comparing across countries the authors find the expected positive relationship (i.e. countries with more competition have better performance) ${ }^{10}$. This positive effect shown by the betweenestimator can be seen as the long-term effect, while the within-estimator captures short-term decreases in average productivity as liberalisation is found to increase employment and this can bring less-than-average-skilled workers on the job market. Several studies also found a significant elasticity of R\&D to tax credit, even more so in the long term (see European Commission, 2002a for a discussion).

\section{Innovation spurs total factor productivity growth.}

\footnotetext{
9 One important determinant of innovation is skills and education as suggested by Rao et al. (2002) and Aghion and Cohen (2004). Griffith and Simpson (2003) found that foreign-owned manufacturing firms in Britain have higher levels of labour productivity and investment per employee. Their results suggest that the higher proportion of skilled workers in foreign-owned industries matches differences in labour productivity.

10 Technically, the difference between the two techniques relates to the presence or not of 'country fixed effects' variables that are there to capture country-specific features which are not observable but may explain better performance and the use or not of the average over time. The authors do not just look across countries because there is always a theoretical risk that country-specific non-observable features other than the level of competition may influence macroeconomic performance and that this impact could be wrongly attributed to the level of competition.
} 
A positive effect of innovation on dynamic efficiency finds additional empirical support. Rao et al. (2001) found a strong correlation between innovation and TFP growth in Canadian manufacturing industries, whilst Wieser (2001) confirmed a positive and significant contribution of R\&D to productivity growth. The R\&D output elasticity could however depend on sectors. Looking at manufacturing firms in Taiwan, Wang and Tsai (2003) found that whilst average output elasticity stood at .18, this effect was larger in high-tech firms. In addition, the effects of R\&D on TFP performance may appear with long lags and investment in ICT could even be associated with lower TFP in the short-run as resources and energy are diverted to reorganisation and learning as suggested by Basu et al. (2003). Aiginger (2004) found that EU Member States that carried out a liberalisation strategy and invested in the same time in knowledge production have done better on average.

However, the relationship between competition and innovation may be of a non-linear nature. Finally, a work by Aghion et al. (2002) suggests that the relationship between competition and innovation may be of a non-linear nature, with both very high and very low levels of product market competition providing lower incentives to innovation. Using a Schumpeterian growth model in which firms innovate step by step (i.e. a laggard firm must first innovate to catch up with the technological leader before becoming itself a leader in the future), where both technological leaders and their followers engage in R\&D activities, and where competition may increase the incremental profit from innovating while reducing innovation incentives for laggards, these authors indeed predict that the relationship between competition and innovation is an inverted U-shape, i.e. the escape competition effect dominates for low initial levels of competition, whereas the Schumpeterian effect dominates at higher levels of competition.

To sum up, the new endogenous growth models predict that the link between competition and innovation may be positive or negative depending on the initial state of competition ("neckand neck' industries versus 'product-differentiated' industries and more generally low level of competition versus high degree of competition) and on the country, industry or firm's initial distance to the world technological frontier.

Empirical studies confirm the non-linear relationship between competition and innovation.

There is however increasing evidence of U-shaped relationship between competition and R\&D or innovation, as predicted by most recent models (Aghion et al. 2002). Griffith and 
Harrison (2004) looked at the link between microeconomic reforms in product markets on macroeconomic performance through their effects on mark-ups. The authors use a two-step approach to link product market reforms and macroeconomic performance. They first identify the link between indicators of product market reforms and economic rents measured by markups. In a second step, they use the predicted mark-up to assess the effect on macroeconomic variables. The authors relate $R \& D$ expenditures with the predicted mark-up from the first regression (indirect effect), its squared value, and policy indicators (direct effect). Their results suggest a non-linear relationship between competition and the levels of $R \& D$ expenditure. However, they find an inverted-U-shape relationship between mark-ups and R\&D that only turns downwards at high levels of regulations. Direct effects of regulation appear to be stronger - although with a negative sign.

Recently, the literature has underlined differential effects of innovation on productivity growth depending on the distance to the technological frontier. As mentioned earlier, Nicoletti and Scarpetta (2003) use an endogenous growth model to integrate productivity growth and catch-up so that product market regulations will both directly and indirectly (through interacting them with the distance to the technological frontier) impact on TFP growth. They found a positive impact of entry on TFP growth, especially in services. These gains seem to be larger the further an economy lies away from the technological frontier. Aghion et al. (2003b) looked at the effects of reforms on trade in India and found the opposite effect. The authors found that Indian States that were close to the technological frontier and had liberalised labour markets enjoyed a positive impact of trade liberalisation on growth, whilst the opposite holds for Indian States that lay far from this frontier.

\section{In the end, the impact of competition on innovation and productivity takes complex forms}

Finally, there is consistent evidence of the importance of technological spillover (Guellec and Van Pottelsberghe, 2001; Bernstein 1996) and of high social rates of return on research and development (Jones and Williams, 1998; Griffith, 2000). In addition, R\&D expenditures have an impact on productivity through two channels: innovation and imitation of other's discoveries (Griffith, Redding and Van Reenen, 2000). The diversity of these findings suggests that, although positive, the impact of competition on innovation and productivity takes complex forms. 
Summing up the transmission channels.

\begin{tabular}{|c|c|}
\hline Channels & Main results \\
\hline Allocative efficiency. & $\begin{array}{l}\text { - Product market reforms increase competition and usually } \\
\text { reduce economic rents (mark-ups) through a reallocation of } \\
\text { resources across firms and, most importantly, inside firms. } \\
\text { - This reallocation of resources positively influences } \\
\text { productivity performance, either directly or, indirectly, by } \\
\text { boosting productive and dynamic efficiency. } \\
\text { - Product market reforms have substantial impact on entry and } \\
\text { exit rate of business. Market contestability appears to be a } \\
\text { necessary condition for the reallocation process to occur. }\end{array}$ \\
\hline Productive efficiency. & $\begin{array}{l}\text { - Increase in competition is associated with increase in } \\
\text { technical or productive efficiency, forcing firms to optimise } \\
\text { the use of available resources. } \\
\text { - Product market competition reduces managerial slack and } \\
\text { increases workers' efforts, raising productive efficiency. }\end{array}$ \\
\hline Dynamic efficiency. & $\begin{array}{l}\text { - In the long-term product market reforms also potentially } \\
\text { affect dynamic efficiency through innovation. More } \\
\text { competition usually leads to TFP growth but with long lags } \\
\text { and mostly through creative destruction. } \\
\text { - Schumpeterian models find that competition reduces the } \\
\text { rents and hence the incentives to innovate. On the opposite, } \\
\text { new endogenous growth models find that competition } \\
\text { increases the incentives to innovate to escape competition. } \\
\text { There is evidence of an inverted U-shaped relationship } \\
\text { between competition and innovation, with too little or too } \\
\text { much competition reducing innovation. In addition, the } \\
\text { technological gap and the type of industry will influence the } \\
\text { incentives for innovation. }\end{array}$ \\
\hline
\end{tabular}




\section{Overall impact of pro-competitive product market reforms on productivity.}



SHORT-TERM / MEDIUM TERM EFFECTS 


\section{Conclusions.}

Product market reforms have been a pillar of economic policy in the European Union. Starting with the removal of trade barriers between 1958 and 1968, measures to open up markets to competition have been pursued with the implementation of the Single Market Programme by the end of 1992. Today, product market reforms remain a key element of the Lisbon strategy and in particular of the Broad Economic Policy Guidelines.

Although these reforms may have a direct impact on the cost of doing business, most of their effects actually translate into productivity increases through three transmission channels. These three channels depend heavily on the competition effects that product market reforms unleash by means of opening up markets to domestic and foreign competitors, removing hurdles to business activities, and levelling the playing field among businesses. Competition immediately puts pressure on the economic rents and creates incentives to companies to both reallocate (allocative efficiency) and use (productive efficiency) their resources in the most efficient way. Those changes that are internal to the firm drive capital and labour productivity increases. Although reallocation of resources via entry and exit does not seem to be the dominant effect, contestability of the markets is a necessary condition for allocative and productive efficiency to sustain in the long-term. In addition, contestability plays an essential role in enhancing dynamic efficiency through creative destruction. Although the relationship is of non-linear nature and depends on the type of industries and on the technological gap, competition generally forces competitors to innovate. This in turn raises productivity growth in the long-term. 


\section{References.}

Acs, Z.J. and B.D. Audretsch (1987), "Innovation, market structure and firm size", Review of Economics and statistics, 69, pp. 567-575.

Aghion, P. and P. Howitt (1992), "A model of growth through creative destruction", Econometrica, 60, pp. 323-351.

Aghion, P., Harris, C. and J. Vickers (1997), "Competition and growth with step-by-step innovation: an example", European Economic Review, Papers and Proceedings, pp. 771-782.

Aghion, P. and P. Howitt (1998), Endogenous Growth Theory, MIT Press, Cambridge and London.

Aghion, P., Harris, C., Howitt, P.and J. Vickers (2001), “Competition, imitation and growth with step-by-step innovation”, Review of Economic Studies, vol. 68, pp. 467-492.

Aghion, P., Bloom, N., Blundell, R., Griffith R., and P. Howitt (2002), "Competition and innovation: an inverted U relationship", NBER Working paper, n9269, October 2002.

Aghion, P, Blundell, R., Griffith, R, Howitt, P, and S. Prantl (2003a), "Firm entry and growth: theory and micro evidence", Mimeo.

Aghion, P., Burgess, R., Redding, S, and F. bilizotti (2003b), "The Unequal Effects of Liberalization: Theory and Evidence from India”, mimeo, http://econ.lse.ac.uk/staff/rburgess/wp/abrz031002.pdf

Aghion, Philippe and Elie Cohen (2004), Education et croissance, Rapport pour le Conseil d'Analyse Economique, Paris.

Ahn, Sanghoon (2001), "Firm dynamics and productivity growth: a review of micro evidence from OECD countries", OECD Economics Department Working Papers, № 297.

Ahn, Sanghoon (2002), "Competition, innovation and productivity growth: a review of theory and evidence", OECD Economics Department Working Papers , Nº 317.

Aiginger, K. (2004), "A three tier strategy for successful European countries in the nineties", International Review of Applied Economics, Vol. 18(4).

Allen, C., M. Gasiorek and A. Smith (1998), "European Single Market: How the programme has fostered competition", Economic Policy, pp. 441-486.

Baily, M.N., Hulten, C. and D. Campbell (1992), "Productivity dynamics in manufacturing plants", Brookings Papers on Economic Activity: Microeconomics, pp. 187-267.

Bain, J.S. (1951), "Relation of profit rate to industry concentration: American manufacturing 1936-1940”, Quarterly Journal of Economics, 65, pp. 293-324.

Bain, J.S. (1956), Barriers to new competition, Harvard University Press, Cambridge, MA.

Barnes, Matthew, Haskell, Jonathan, and Mika Maliranta (2001), "The sources of productivity growth: micro-level evidence for the OECD", Paper presented at the OECD workshop on firm-level statistics, OECD, November 2001, Paris. 
Basu, Susato; Fernald, John G.; Oulton, Nicholas, and Sylaja Srinivasan (2003), "The case of missing productivity growth: or, does information technology explain why productivity accelerated in the United States but not in the United Kingdom?", NBER Working paper, ${ }^{\circ}$ 10010, Cambridge, MA.

Bayoumi, T., D. Laxton and P. Pesenti (2004), "Benefits and spillovers of greater competition in Europe: a macroeconomic assessment", European Central Bank Working Paper Series, ${ }^{\circ}$ 341.

Bernstein, Jeffrey (1996), "R\&D and productivity growth in Canadian communication equipment and manufacturing", Industry Canada Working Paper.

Bils, M. (1987), "The cyclical behaviour of marginal cost and price", American Economic Review, 77, pp. 838-885.

Blanchard, Olivier and Giavazzi (2001), "Macroeconomic Effects of Regulation and Deregulation in Goods and Labor Markets", MIT Department of Economics, Research Paper Series, ${ }^{\circ} 01-02$, January 2002.

Blinder, A., E. Canetti, D. Lebow and J. Rudd (1998), Asking about prices: a new approach to understanding price stickiness, Russel Sage Foundation, New York.

Blundell, Richard W., Griffith, Rachel, and John Van Reenen (1999), "Market share, market value and innovation in a panel of British manufacturing firms", Review of Economic Studies, n66, pp. 529-554.

Boone, Jan (2000), "Competition”, Centre for Economic Policy Research, Discussion Paper Series, $\mathrm{N}^{\circ} 2636$.

Brandt, Nicola (2004), "Business dynamics, regulation and performance", STI Working papers, 2004/3, OECD, Paris.

Cincera, Michele (2004), The impact of market entry and exit on EU productivity and growth performance, Study for the European Commission, forthcoming.

Caves, Richard E. and D.R. Barton (1990), Efficiency in US manufacturing industries, MIT Press, Cambridge, MA.

Caves, Richard E. et al. (1992), Industrial Efficiency in Six Nations, Cambridge, MA, MIT Press

Cecchini, P., M. Catinat and A. Jacquemin (1988), The European challenge -1992- The benefits of a Single Market, Wilwood House, Adelshot.

Clark, Steven (2002), "Corporate tax incentives for foreign direct investment", paper presented at the OECD global forum on international investment, Shanghai, 5-6 December 2002.

Cullen, Julie Berry and Roger H. Gordon (2002), "Taxes and entrepreneurial activity: theory and evidence for the US", NBER Working paper, $\mathrm{n}^{\circ} 9015$.

Dasgupta, Partha and Joseph Stiglitz (1980), "Industrial structure and the nature of innovative activity”, Economic Journal, 90, pp. 266-293. 
De Mooij, Ruud and Sjef Ederveen (2001), "Taxation and foreign direct investment: a synthesis of empirical research”, CPB discussion paper, n³, November 2001.

Demsetz, H. (1974), "Two systems of belief about monopoly", in H.J. Goldschmid, H.M. Mann and J.F. Weston (Eds), Industrial concentration: the new learning, Little, Brown, MA.

Denis, Cécile; McMorrow, Kieran; and Werner Röger (2004), "An analysis of EU and US productivity developments", Economic Papers, n² 208, European Commission, Brussels.

Disney, Richard F \& Haskel, Jonathan \& Heden, Ylva, 2000. "Restructuring and Productivity Growth In UK Manufacturing," CEPR Discussion Papers n²463.

Domowitz, I., R. G. Hubbard and B. C. Petersen (1988), "Market structure and cyclical fluctuations in U.S. manufacturing", The Review of Economics and Statistics, 70 (1), pp. 5566.

European Business Monitor, http://ebm.ups.com/europe/ebmxiii/en_pdf.html

European Central Bank (2004), "Measuring and analysing profit developments in the euro area", Monthly Bulletin, January, 63-73.

European Commission (1996), "Economic evaluation of the Internal Market", European Economy, reports and studies, $\mathrm{N}^{\circ} 4$.

European Commission (2000), "Setting the stage: a simple growth-accounting exercise", in the EU economy: 2000 review

European Commission (2001), Company taxation in the internal market, $\operatorname{COM}(2001) 582$ final.

European Commission (2002a), "Corporation tax and innovation”, Innovation papers, $\mathrm{n}^{\circ} 19$.

European Commission (2002b), "Structural reforms in labour and product markets and macroeconomic performance in the EU", in the EU Economy: 2002 Review.

European Commission (2002c), The Internal Market - ten years without frontiers.

European Commission (2003), "Drivers of productivity growth: an economy-wide and industry level perspective", the EU Economy: 2003 Review.

European Commission (2004), European Tax Survey, SEC(2004)1128.

Gentry, William M. and R. Glenn Hubbard (2004), "Success taxes, entrepreneurial entry, and innovation", NBER Working paper, n 10551, June 2004.

Geroski, P., P. Gregg and J. Van Reenen (1996), "Market imperfections and employment", OECD Economic Studies, № 26, I, pp. 117-156.

Griffith, Rachel (2000), "How important is business R\&D for economic growth and should the government subsidise it?”, IFS Briefing notes, Institute for Fiscal Studies, October 2000.

Griffith, Rachel, Redding, Stephen and John Van Reenen (2000), "Mapping the two faces of R\&D: productivity growth in a panel of OECD studies", IFS working paper, $\mathrm{n}^{\circ} 02 / 00$. 
Griffith, Rachel (2001), "Product market competition, efficiency and agency costs: an empirical analysis", Institute for Fiscal Studies, Working Paper 01/12, June.

Griffith, Rachel and Rupert Harrison (2004), "The link between product market reform and macro-economic performance", Economic Paper, n² 209, European Commission.

Griffith, Rachel and Helen Simpson (2003), "Characteristics of Foreign-Owned Firms in British Manufacturing”, NBER Working paper, $\mathrm{n}^{\circ}$ 9573, Cambridge, MA.

Griliches, Zvi and Haim Regev (1995), Journal of Econometrics, vol 65, no. 1, pp.175-203.

Green, A. and D.G. Mayes (1991), "Technical efficiency in manufacturing industries", Economic Journal, 101, pp. 523-538.

Guellec, Dominique and Bruno Van Pottelsberghe (2001), "R\&D and productivity growth: panel data analysis of 16 OECD countries”, OECD Economic studies, n³3, Paris.

Hall, R.E (1986), "Market structure and macroeconomic fluctuations", Brookings Papers on Economic Activity, 2, 285-322.

Hall, R.E. (1988), "The relation between price and marginal cost in US industry", Journal of Political Economy, 96 (5), pp. 921-947.

Hall, S., M. Walsh and A. Yates (2000), “Are UK companies' prices sticky?", Oxford Economic Papers, 52, pp. 425-446.

Harberger, A.C. (1954), "Monopoly and resource allocation", American Economic Review, Vol. 44, N², pp. 77-87.

Harrison, Ann E.. (1994), "Productivity, imperfect competition and trade reform. Theory and evidence.”, Journal of International Economics, 36, pp. 53-73.

Haskel, J. (1991), "Imperfect competition, work practices and productivity growth", Oxford Bulletin of Economics and Statistics, Vol. 53 (3), pp. 265-79.

Holmstrom, B. (1982), "Managerial Incentives Problems - A dynamic perspective", in: Essay in economics and management in honour of Lars Wahlbeck, Swedish School of Economics, Helsinki.

IMF (2003), "Unemployment and labor market institutions: why reforms pay off", in IMF World Economic Outlook, April, Chapter IV.

Jacquemin, A. and A. Sapir (1991), "Competition and imports in the European market", in L.A. Winters and A.J. Venables (Eds), European integration: trade and industry, Cambridge University Press, Cambridge.

Jagannathan, R. and S.B. Srinivasan (2000), "Does product market competition reduce agency costs?”, NBER, Working Paper Series, 7480.

Jones, Charles and John Williams (1998), "Measuring the social return to R\&D", Quarterly Journal of Economics, Vol. 113, Nov. 1998, pp. 1119-1135.

Keuschnigg, Christian and Soren Bo Nielsen (2000), "Tax policy, venture capital and entrepreneurship", CEPR Discussion Papers n`2626. 
Konings, J., P. Van Cayseele and F. Warzynski (2001), "The dynamics of industrial markups in two small open economies: does national competition policy matter?", International Journal of Industrial Organization, 19, pp. 841-859.

Leibenstein, H. (1966), "Allocative efficiency versus X-efficiency", American Economic Review, 56, pp. 392-415.

MacDonald, James M. (1994), "Does import competition force efficient production?", Review of Economics and Statistics, 76, pp. 721-727.

Machin, Stephen and John Van Reenen (1993), "Profit Margins and the Business Cycle: Evidence from UK Manufacturing Firms", Journal of Industrial Economics, Volume 41, No. 1, March 1993.

Melitz, Marc (2003), "The impact of trade on intra-industry reallocations and aggregate industry productivity", Harvard, Mimeo, forthcoming in Econometrica.

Meyer, M.A. and J. Vickers (1997), "Performance comparisons and dynamic incentives", Journal of Political Economy, 105(3), pp. 547-581.

Mookherjee, D. (1984), “Optimal incentives schemes with many agents”, Review of Economic Studies, 51, July, pp. 433-446.

Nalebuff, B. and J. Stiglitz (1983), "Information, competition and markets", American Economic Review, 73, 278-283.

Nicoletti Giuseppe and Stefano Scarpetta (2003), "Regulation, productivity and growth: OECD evidence”, Economic Policy, vol. 18, no. 1, April 2003, pp. 9-72(64)

Nickell, S., S. Wadhwani and M. Wall (1992), "Productivity growth in UK companies, 197586", European Economic Review, 36, pp. 1055-1091.

Nickell, S.J. (1996), "Competition and corporate performance", Journal of Political Economy, vol. 104, $\mathrm{N}^{\circ} 4$, pp.724-746.

Nickell, S., D. Nicolitsas and N. Dryden (1997), "What makes firms perform well”, European Economic Review, 41, pp. 783-796.

Oliveira Martins, Joaquim; Scarpetta, Stefano and Dirk Pilat (1996) "Mark-up ratios in manufacturing industries - Estimates for 14 OECD countries", OECD Economics Department Working Papers, ${ }^{\circ} 162$, Paris.

Organisation for Economic Cooperation and Development (2004), Understanding economic growth.

Pilat, Dirk (1996), "Competition, Productivity and Efficiency", OECD Economic Studies, $\mathrm{n}^{\circ} 27$, Paris.

Rao, Someshwar; Ahmad, Ashfaq; Horsman, William and Phaedra Kapstein-Russell (2001), "The importance of innovation for productivity", International Productivity Monitor, n², Spring 2001. 
Rao, Someshwar; Tang, Jianmin, and Weimin Wang (2002), "The importance of skills for innovation and productivity”, International Productivity Monitor, n, Spring 2002.

Rivaud-danset, D., E. Dubocage and R. Salais (2001), "Comparison between the financial structure of SMES and that of large enterprises (LES) using the BACH database", European Commission Economic Papers, $\mathrm{N}^{\circ} 155$.

Roeger, W. (1995), "Can imperfect competition explain the difference between primal and dual productivity measures? Estimates for US manufacturing", Journal of Political Economy, 103 (2), 316-330.

Romer, Paul M. (1990). "Endogenous technological change", Journal of Political Economy, Vol.98, pp. 71-102.

Sauner-Leroy, Jacques-Bernard (2003), "The impact of the implementation of the Single Market Programme on productive efficiency and on mark-ups in the European Union manufacturing industry", European Commission Directorate-General for Economic and Financial Affairs, Economic Papers, No 192.

Scherer, F. and Ross, D. (1990), Industrial Market Structure and Economic Performance, 3rd ed., Houghton Mifflin, Boston.

Sharpe, Andrew (1995), "Productivity concepts, trends and prospects: an overview", Review of economic performance and social progress, vol.2.

Schmalensee, R. (1989), "Studies of structure and performance", in R. Schmalensee and R. Willig (Eds), Handbooks of industrial organization, vol. 2, Elsevier Science Publishers, Amsterdam, North-Holland.

Sutton, John (2002), "Market structure: the bounds approach", mimeo, http://personal.1se.ac.uk/sutton/market structure bounds sutton.pdf

Vickers, J. (1995), “Concepts of Competition”, Oxford Economic Papers, 47.

Wang, Jiann-Chyuan and Kuen-Hung Tsai (2003), "Productivity growth and R\&D expenditure in Taiwan's manufacturing firms", NBER Working paper, ${ }^{\circ}$ 9724, Cambridge, MA.

Wieser, Robert (2001), "The impact of research and development on output and productivity: firm level evidence", in Innovation and productivity of European Manufacturing, Austrian Institute for Economic Research WIFO, study for the European Commission.

Winston, C. (1993), "Economic deregulation: days of reckoning for microeconomists", Journal of Economic Literature, Vol. 31, September, pp. 1263-1289. 


\section{Appendix I: definition of product market reforms}

Product market reforms are structural reforms of microeconomic type that aim to improve the functioning of product markets by increasing competition among producers of goods and services. There are four types of measures that may be taken to reform product markets:

- First, measures to open up markets (goods and services) that were previously sheltered from competition from abroad by tariff barriers (trade openness) or legal barriers (liberalisation).

- Second, measures to open up markets that were previously sheltered from competition from newcomers - whatever their origin - because of stringent regulations on entry, such as permits and licences, or non-tariff barriers, such as specific national regulations (deregulation).

- Third, measures to create a more business-friendly environment, such as the reduction of time and costs to set up a new company.

- Fourth, measures that seek to reduce the State' involvement in the economy, since this is likely to disturb the well functioning of markets (ad hoc State aid, subsidies and State-owned firms competing with private firms).

The implementation of the Single Market Programme was intended to abolish all barriers to the free movement of goods, services, persons and capital within the European Union by the end of 1992. This programme constitutes the most recent comprehensive exercise of product market reform. The 1988 Cecchini report sought to measure the foreseeable effects of these measures. Notably, it considered that the expected economic gains from the completion of the internal market would stem from the intensification of competition between producers, from efficiency gains resulting from the reduction of trade barriers and from economies of scale induced by the expansion of markets. This would lead to the intensification of competition on the goods and services markets together with the realisation of productivity gains that were supposed to translate into lower product prices. This in turn would lead to a virtuous circle of reduction of inflationary pressures, increases in consumers' purchasing power, and stimulation of demand favourable to GDP growth in Europe.

Major reforms that have affected European countries not only include the range of Single Market measures but also liberalisation and regulatory reform in network industries, reduction in state aids, reforms of competition policy, entry requirements and privatizations (Griffith and Harrison, 2004). 


\section{Appendix II: Measure of the mark up}

Numerous studies using macroeconomic databases have sought to measure the level of markups within the manufacturing industry of various countries. Studies using macroeconomic databases generally make use of econometric techniques for estimating the mark-up ratio. Based on the methodology used for calculating total factor productivity, the so-called Solow residual, this technique consists of using a regression analysis with an output as dependent variable and the production factors, or inputs, as explanatory variables. The residual of the equation is a proxy of the Lerner index $(B=p-m c / p)^{11}$ which is a traditional indicator measuring the degree of competition. This methodology, first proposed by Hall (1986 and 1988), supplemented by Domowitz et al. (1988) then modified by Roeger (1995), makes it possible to estimate indirectly the mark-up ratio ${ }^{12}$ (Oliveira Martins et al., 1996).

However, as the marginal cost is unobservable, one generally uses average variable cost as a proxy for marginal cost (Ahn, 2002) and - because one assumes that returns to scale are constant - estimates of the mark-up based on Roeger's method are in fact estimates of the difference between price and average costs (Oliveira Martins et al., 1996). Another way of calculating the mark-up is to compute a profit mark-up indicator as the ratio of gross value added over unit labour costs. However, this indicator is only a crude approximation, as it does not take into consideration corporate taxes and interest payments (European Central Bank, 2004).

Some authors, using accounting and financial databases, use average cost, or even variable cost, as a proxy of marginal cost and calculate either a direct measure of the Lerner index (Nickell, 1996; Aghion et al., 2002), or a direct measure of the mark-up by calculating the "turnover/variable cost" ratio from aggregated accounting data (Griffith, 2001). Others use the ratio of gross operating profit over value added (Rivaud-Danset et al., 2001). This way of computing the mark-up ratio, i.e. by using the average costs, seems to be consistent with business practices as regards price setting. Indeed, surveys conducted within UK (Hall et al., 2000) or American firms (Blinder et al., 1998) have shown that production costs, i.e. unit costs, were more widely used for price setting than marginal cost.

\footnotetext{
11 B: Lerner index; $\mathrm{p}=$ prices; $\mathrm{mc}=$ marginal cost.

12 The relation between the mark-up and the Lerner index is as follows: $\mathrm{p} / \mathrm{mc}=1 /(1-\mathrm{B})$.
} 
If high profit levels can be interpreted as a consequence of low competitive pressures, in contrast they can also result from efficient behaviour of firms (Ahn, 2002). For instance, Demsetz (1974) considered that high profit levels within an industry can be explained by good performances of firms, i.e. their ability - mainly for largest firms - to produce at low costs. In the same vein, Boone (2000) showed that an increase in competition does not necessarily translate into a reduction of mark-ups in particular for the most efficient firms. More generally, an increase in competition may have more effects on prices than on profits, and therefore the mark-up may remain stable while prices may fall. Geroski et al. (1996) showed in particular that this is likely to occur because incumbent firms have excess costs such as managerial slack or rent sharing with the workforce - which can be reduced to compensate for lower prices. This latter argument could be a good explanation for the paradox mentioned by Konings et al. (2001) concerning the levels of mark-ups in the Dutch manufacturing sectors facing high import rates. The authors found mark-ups to be higher in these sectors than in sectors where import rates were low. If the intensity of competition results in a fall in costs that is larger than the fall in prices, then profit (the price-cost margin) increases.

As the effects of competition on the mark-up ratio may be ambiguous, its evolution over time has to be analysed simultaneously with the evolution of its two components, namely prices and unit costs (Bils, 1987; Machin and Van Reenen, 1993). Applying this methodology to analyse the impact of the implementation of the Single Market Programme has had on mark ups in the European manufacturing industry, Sauner-Leroy (2003) found evidence that profit margins of EU firms in the early 1990's declined in line with a decrease in real prices. He found that this phenomenon could be at least partly attributable to increased competition stemming from intra-EU imports, thus indicating the realisation of allocative efficiency gains induced by the intra-EU trade liberalisation. 